\title{
MIGRATION DUE TO SEXUAL ORIENTATION AND GENDER IDENTITY
}

\author{
MIGRAÇÃO EM RAZÃO DE PERSEGUIÇÃO POR ORIENTAÇAO \\ SEXUAL OU IDENTIDADE DE GÊNERO
}

\author{
Daniel Braga Nascimento ${ }^{1}$ \\ Emilie de Haas $^{2}$ \\ Roberta Camineiro Baggio ${ }^{1}$
}

\section{Recebido em: 09/04/2017 Aceito em: 06/07/2017 \\ danbragan@yahoo.com.br emilie.dehaas@mail.mcgill.ca robertabaggio@uol.com.br}

Abstract: The concept of the term refugee is set out in Art. 1, item I of the Law 9.474 / 97 of the Foreign Statute of Brazil, which defines a refugee as any individual with a well-founded fear of persecution due to race, religion, nationality, political opinion or social group. The Convention of 1951 does not establish a specific category for persecution related to sexual orientation or gender identity. In many countries homosexuality is punished by imprisonment, or the death penalty (Saudi Arabia, Iran, Yemen, Mauritania and Sudan, as well as in regions of Nigeria and Somalia), among other penalties that deny full citizenship, segregate, discriminate and deny rights to this group. Due to the persecution these individuals suffer in their home countries, it is possible to ask: were gay, lesbian, bisexual, transgender and intersex individuals included in the social group category due to its flexible criteria? The United States, Canada and several European countries have been accepting refugee applications for individuals with well-founded fear of persecution because of their sexual orientation or gender identity. By employing this criterion, the CONARE (National Committee for Refugees of Brazil) has granted refuge to gay, lesbian, bisexual, transgender and intersex individuals who are persecuted in their home countries due to their sexual orientation or gender identity. This article explores the concept of the term refugee and its expansion over the past years, focusing especially on the basis of the refugee criterion related to social group. The aim is therefore to analyze the category of social group in the concept of refugee. It also aims to examine the possibility of framing said populations in the category of social group in order to facilitate their obtainment of a Refugee status.

Keywords: Asylum. LGBT. Migration. Persecution. Refugees.

Resumo: O conceito de refugiado é expresso no Art. $1^{\circ}$ Inciso I, da Lei 9.474/97 (Estatuto do Estrangeiro), definindo refugiado como todo indivíduo que apresenta fundado temor de perseguição em decorrência de raça, religião, nacionalidade, grupo social ou opinião política. A convenção de 1951 não apresenta uma categoria específica para perseguidos em função da orientação sexual ou identidade de gênero. Em diversos países a homossexualidade é punida com prisão, pena de morte (Arábia Saudita, Irã, Iêmen, Mauritânia e Sudão -além de regiões da Nigéria e da Somália), entre outras penas que impedem a cidadania plena, segregam, discriminam e negam direitos a esse grupo. Diante da perseguição que esses indivíduos sofrem em seus países de origem, pergunta-se: estariam gays, lésbicas, bissexuais, transexuais e intersexuais incluídas na categoria de grupo social, pois essa é mais flexível? Estados Unidos, Canadá e diversos países europeus, vêm aceitando pedidos de refúgio por indivíduos que apresentam fundado temor de perseguição em decorrência de sua orientação sexual ou identidade de gênero. Na mesma senda, através desse critério, o CONARE (Comitê Nacional para os Refugiados) concedeu refúgio para gays, lésbicas, bissexuais, transexuais e interssexuais que sofrem perseguição em seus países de origem em decorrência de sua orientação sexual ou identidade de gênero. O presente artigo explora o conceito de refugiado e sua expansão no decorrer dos últimos anos, especialmente no critério de concessão baseado em grupo social. Busca-se, então, analisar a categoria do grupo social dentro do conceito de refugiado. Ainda, especificamente, a possibilidade de enquadramento das populações supramencionadas na categoria de grupo social para que possam gozar do estatuto de refugiado.

Palavras-chave: Asilo. LGBT. Migração. Persecution. Refugiados.

\footnotetext{
${ }^{1}$ Universidade Federal do Rio Grande do Sul - UFRGS - Porto Alegre - Rio Grande do Sul - Brasil

${ }^{2}$ University McGill - Montreal - Quebec - Canadá
} 


\section{INTRODUCTION}

The search for a better life has always been one of humanity's greatest objectives. Being able to develop one's personal identity constitutes an integral part of this objective. Zygmunt Bauman, in his work entitled Identity, describes the quest as such

what we all seem to fear, in the light of the day or haunted by night hallucinations, is the abandonment, exclusion, rejection, being banned, be rejected, discarded, stripped of what it is, not having permission to be what you want to be. We are afraid of being left alone, helpless and miserable. (2005, p. 99)

Globally, LGBTI individuals are subject to violence, punishment, incarceration and death. These acts of persecution are frequently perpetrated by state officials or with the State's knowledge, as well as by individuals. As a result of this persecution, many people who identify as LGBTI are forced to flee their countries and cross borders in search of protection.

Seeking asylum is an option available to LGBTI persons. However, International Refugee Law requires there to be a demonstrable link between the asylum seeker and a risk of persecution in his or her native state. The Convention Relating to the State of Refugees of 1951 does not explicitly include persecution due to sexual orientation or gender identity as criteria for the granting of refugee status. Nor does the Protocol Relating to the Status of Refugees of 1967.

To this day, legislation in a considerable number of countries recognizes LGBTI persons as members of a particular social group. This recognition has allowed asylum seekers to establish the necessary link between their sexuality and a well-founded fear of persecution to allow for them to successfully claim refugee status. This evolution in the interpretation of the law on refugees reflects a larger move towards the recognition of LGBTI rights in international law and in the domestic jurisprudence of several states. While the link between sexual orientation and asylum legislation is recognized in certain states, doubts arise as to which criteria should be employed to grant asylum based on a well-founded fear of persecution due to sexual orientation or gender identity. More to the point, how can the criteria of social group found in refugee law be outfitted to serve LGBTI persons in their request for asylum?

Images and stories of intolerance directed at the LGBT population periodically surface in the news from practically every corner of the globe: from countries whose legislations oppress the LGBT community either by death penalty, corporal punishment or incarceration, to countries whose laws point to a clear will to protect the rights of this social group.

\section{LGBTS REFUGEES}

Revista do Direito [ISSN 1982-9957]. Santa Cruz do Sul, v. 1, n. 51, p. 58-67, jan./abr. 2017. https://online.unisc.br/seer/index.php/direito/index 
According to the United Nations, there are 191 countries in the world to date. Of these 191 countries, 88 of them maintain legislationin disfavour of homosexuality. In 72 countries, a homosexual person can be arrested for his or her sexual orientation. Finally, in 7 countries, homosexuality is punishable by death penalty. How is one to live in a country where his or her homosexual identity is condemned by capital punishment?

In Uganda, a bill that sought to punish affectionate and/or suspicious homosexual behaviour by imprisonment or by death penalty raised further debate surrounding the topic after international media reported some incidentes

in seeking to imprison or execute the half-million lesbian, gay, bisexual, and transgendered ("LGBT") people in Uganda, the Bill sparked a nationwide flare of homophobia, where citizens, politicians, and the media have branded homosexuals as "un-African," as threats to children, and as "less than human." Since David Bahati introduced the Bill on October 14, 2009 , violence against LGBT people has escalated, including "beatings, disappearances, 'corrective' rapes of lesbians, vigilante squads and church crusades, [and] preachers calling out 'homos' in their own pews." Furthermore, media in Uganda have published lists, including names and addresses, of suspected homosexuals. These people have been attacked, humiliated, and forced into hiding. In January 2011,David Kato, a prominent LGBT activist who had been outed as homosexual in a Ugandan tabloid, was bludgeoned to death in his own home, an incident that sparked international outrage. Many LGBT people, and those suspected of being LGBT, are trying to emigrate from "this deadly place.

Seeking asylum thus becomes a juridical remedy for those who are victims of discrimination, segregated and whose rights are denied or ignored by the State. Left without a choice, individuals are forced to flee their countries in the search for protection in other states. Brazil's CONARE (Comitê Nacional para os Refugiados) has granted asylum to gays, lesbians, bisexuals, transsexuals and intersexuals who suffer persecution in their countries of origin as a consequence of their sexual orientation or gender identity.

Article 1 of the Convetntion of 1951 states the following

for the purpose of the present Convention, the term "refugee" shall apply to any person who:

I - owing to well- founded fear of being persecuted for reasons of race, religion, nationality, membership of a particular social group or political 
opinion, is out- side the country of his nationality and is unable or, owing to such fear, is unwilling to avail himself of the protection of that country;

II - not having a nationality and being outside the country of his former habitual residence as a result of such events, is unable or, owing to such fear, is unwilling to return to it.

III - [ ...]

Article 1 of the Universal Declaration of Human Rights establishes that "all human beings are born free and equal in dignity and rights". Article 2 declares, "everyone is entitled to all the rights and freedoms set forth in this Declaration". All persons, including LGBTI individuals have the right to enjoy protection under International Law of Human Rights in a unanimous and non-discriminatory manner.

The CONARE decided that LGBT asylum seekers also fit the description of refugees set out in the Convention, given their motives for fleeing due to the persecution, criminalization and social exclusion they suffer in their native countries. According to data collected by the UN's High Commission for Refugees, Brazil is currently home to 7, 600 refugees residing in the country, of which a small portion (18) have been recognized for having been persecuted due to their sexual orientation or their gender identity. Another twenty-three requests for asylum based on the very same motives are pending approval.

According to the CONARE's interpretation, gays, lesbians, bisexuals, transsexuals and intersexuals are individuals that belong to a determined social group. As such, they deserve to be recognized as refugees when they are forced to flee their native countries due to persecution, criminalization or social isolation that they suffer or run the risk of suffering in virtue of their sexual orientation.

Nevertheless, immigration tribunals in different parts of the world are developing diverging interpretations of the concept of a social group. For example, in the United States, the determination of members of social groups have brought forth questions such as the relevance of the "social visibility" characteristic as a way of determining a social group. Among the five possible criteria for the granting of asylum, participation in a social group has always been at the root of major debates. The dominant, internationally shared vision for the concept of the composition of a social group is the recognition of an "immutable" characteristic proper to the individuals that comprise it (MAROUF, 2008, p. 48), a characteristic that cannot be altered or should not be required to be altered by the individuals because they are fundamental to their identities and consciences.

Partisans of this approach include the aforementioned United States, as well as Canada, New Zealand and the United Kingdom. All four follow the principle of "protected characteristics" (MAROUF, 2008, p. 48). Alternatively, Australia emphasizes "social perceptions", in conjunction with the consideration of immutable or protected characteristics.

In 2002, the United Nations High Commissioner for Refugees published guides that identified both "immutable characteristic" and "social perception" as alternative reference points to establish an individual's inclusion in a said social group. These guides instructed states to firstly determine if there existed a protected characteristic that warranted participation in a social group and in the event that 
there wasn't such a characteristic, to turn to the observable society to determine if said social group was recognized by it.

Despite these guidelines, the United States favour the asylum seeker's individual visibility over the collective visibility of the social group to which he or she claims to belong. To determine his or her refugee status, the applicant must visibly display his or her sexual orientation, rather than meet the established criteria of active participation in a determined social group. In short, the use of a subjective criterion as opposed to an objective criterion is employed when choosing whether or not to grant refugee status.

Such a subjective criterion as outer visibility goes against the Convention relating to the Status of Refugees of 1951, as well as the Additional Protocol of 1967, because it disregards the objectively identifiable character of a given social group by focusing too largely on individual characteristics of applicants. Such an approach breaks away from judicial decisions in international immigration courts and leads to an impact on the decisions revolving around the granting of refugee status for motives of sexual orientation or gender identity.

The moment a court adopts the "visibility" criterion as a requirement for the granting of refugee status, a LGBTI individual who may be of a discrete nature sees his or her chances of receiving refugee status reduced dramatically. Furthermore, this approach ignores the fact that some countries do not consider homosexuals a social group or homosexuality as a social identity.

In the national doctrine, Liliana Jubilut explains that

the definition of a social group is not precise, and its inclusion in the list of motives for which asylum is granted was intended precisely for its vagueness: it was concluded that no exhaustive definition of who or who did not qualify as a refuge would cover all cases of all individuals in need of such protection. At the same time, it was the indispensability of an international stance that called for a homogeneous practice of the institution, creating therefore a necessity to agree on an establish set of criteria (JUBILUT, 2007, P.132, our translation)

Thus, the affiliation to a certain social group was created as a residual motive, malleable in nature in order to guarantee justice to refugees. In conformity to Jubilut (2007), there exists three criteria to define a social group: (1) social cohesion in the identification of the said group; (2) societal context, evaluated by how society perceives the social group in question, if it is able to identify it as a distinct group or not; (3) the discretion of the persecuting agent - most adequately used when granting refugee status - referring to the observation of the persecuting agent's stance towards the group in question, or by the behaviour of the agent before an individual from the said group. Discriminatory behaviour suffices to establish the existence of a social group.

\section{THE COURTS OF IMMIGRATION AROUND THE WORLD}


The first time a country recognized sexual orientation as a motive for persecution and delineated LGBTIs as a social group was in the Netherlands, in the case of Afdelingrechtspraak van de Raad van State (Judicial Division of the Council of State), 13 August 1981, RechtspraakVreemdelingenrecht 1981, 5, GidsVreemdelingenrecht (oud) D12-51, in conformity with the report entitled Fleeing Homophobia. According to the report, depending on the circumstances in the country of origin, the concept of a particular social group in the definition of a refugee may apply to a group based on the common characteristic of sexual orientation.

For T. David Parish, the social group category is a "catch all and should be flexibly interpreted". (PARISH, 1992, p.926) Neither the Protocol nor the Convention explicitly define or give examples of the term "social group". The origins of the term could point to indicators of the original objective of its use in granting the status of refugee. According to Parish, "perhaps the meaning of this term was intended to remain indefinite in order to allow for situations that had been overlooked and to retain flexibility in dealing with future exigencies." (PARISH, 1992, p. 928)

Once again looking to the United States (Henes, 1994, p. 377), the 1993 case of Marcelo Tenorio, a Brazilian asylum seeker identifying as homosexual,is of much relevance. The San Francisco judge in the case, Philip Leadbetter, granted refugee status to Tenorio, supporting his judgment with the argument that homosexual individuals belonged to a distinguished social group subject to persecution in Brazil. In the respondent's account on the persecution he suffered in Brazil, it was recounted as such

the respondent testified that he is homosexual. He has been a practicing homosexual since the age of fourteen. He asserted that he is afraid to return to Rio de Janeiro due to an incident that occurred in 1989. Respondent explained this incident as follows: respondent left a gay discotheque, 'Encontro', and walked through a small park to the bus stop in front of the club. He stood alone at this bus stop at approximately 3:00 a. $\mathrm{m}$. waiting for the bus to go home. (...). While respondent was standing at the bus stop, a car stopped near him. Individuals in the car yelled at him that he was gay. They got out of the car and called him a "faggot," "gay" and similar names and swore at him. (...) They began to beat him. They told him that if he returned to the discotheque or was found in that area again that they would get him again and it would be worse the next time. One man got out of the car, pulled out a knife and stabbed respondent in his side. After being attacked, respondent fainted.

The analysis of the judge's decision points to the acceptance of the theory that supports the idea that LGBTIs belong to a distinct social group. For Leadbetter (1993), 
[Sexual orientation is] an immutable characteristic, and one which an asylum applicant should not be compelled to change. Thus, homosexuals are considered to be members of a particular social group.

In the Handbook on Procedures and Criteria for Determining Refugee Status, it is explicitly stated that where homosexuality is considered illegal, the imposition of severe penalties for homosexual conduct can generate persecution. Even in societies where homosexuality is not criminalized, an asylum seeker could make a valid claim for refugee status if the state in which he or she resides tolerates discriminatory practices or detriments perpetrated against him or her, or if the state in question is not effective in protecting the individual from the possible harm suffered. (United Nations Handbook on Procedures and Criteria for Determining Refugee Status, p. 83)

Furthermore, according to the Handbook, the term social group is described as "a group of persons who share a common characteristic other than the risk of being persecuted, or who are perceived as a group by society. The characteristic will often be one which is innate, unchangeable, or which is otherwise fundamental to the identity, conscience or the exercise of one's human rights". (Handbook, 2011, p. 85)

We find further support of this article in Sabine Jansen and Thomas Spijkerboer's report entitled Fleeing Homophobia (2011). The report presents data collected in various European countries considered to be pioneers in granting asylum to LGBTIs. According to the report, the European countries who partake in the refugee program receive 8459 applications for refugee status from LGBTIs on an annual basis. Most countries do not collect data on the number of applications they receive. Nevertheless, Belgium and Norway present interesting data on the matter:

Table 1: LGBTI decisions in Belgium

\begin{tabular}{llll}
\hline Year & Total asylum decisions & LGBTI asylum decisions & $\begin{array}{l}\text { Percentage of LGBTI asylum } \\
\text { decisions }\end{array}$ \\
\hline 2008 & 8.964 & 226 & $2,52 \%$ \\
\hline 2009 & 8.883 & 362 & $4,08 \%$ \\
\hline 2010 & 13.170 & 522 & $3,96 \%$ \\
\hline Total 2008-2010 & 31.017 & 1.110 & $3,58 \%$ \\
\hline
\end{tabular}

Source:Commissariat Général aux Réfugiés et aux Apatrides, Annual Reports, www.cgra.be/fr/Publications/2_Rapport_annuel/, last accessed 28 July 2011

Table 2: LGBT decisions in Norway

\begin{tabular}{lllllll}
\hline Year & Total asylum decisions & \multicolumn{2}{l}{ LGBT asylum decisions } & \multicolumn{2}{l}{ LGBT \% } \\
\hline 2008 & 9.700 & 2 & $\sigma^{x}$ & 1 & 3 & $0,03 \%$ \\
\hline 2009 & 15.686 & $17 \sigma^{x}$ & 0 & $q$ & 17 & $0,11 \%$ \\
\hline 2010 & 16.455 & $19 \sigma^{x}$ & $7 \%$ & 26 & $0,15 \%$ \\
\hline Total 2008-2010 & 41.841 & $38 \sigma^{x}$ & 8 & $q$ & 46 & $0,11 \%$ \\
\hline
\end{tabular}

Source: Norwegian Directorate of Immigration, www.udi.no/Norwegian-Directorate-of-Immigration/Oversiktsider/Statistikk-/Asy/um/Asylum-decisions-in-first-instance-

The United Nations High Commission for Refugees is seeking to amplify state knowledge and sensitivity to this question with the launching of publications and technical guides to assist states in their decisions relating to the pleas of asylum seekers persecuted for sexual orientation or gender diversity motives.Various documents have been made available via Internet, such as the UNHCRGuidance Note on Refugee Claims Relating to Sexual Orientation and Gender Identity (2008), the Round Table on The Protection of Lesbian, Gay, Bisexual, Transgender and Intersex Asylum- 
Seekers and Refugees (2010), and the Basic Gide on Working with Lesbians, Gays, Bisexuals, Transgender \& Intersex Persons in Forced Displacement (2011). More recently, the UN Guidelines on International Protection No. 9 (2012) also address this issue.

The Convention of 1951 does not establish an institutional organ responsible for the interpretation of the criteria in the granting of refugee status. Having said so, the UNHCR provides guidelines with the end goal of orienting potential controversies emerging from diverging interpretations of these criteria. The UNHCR guidelines serve to legally orient the interpretation for governments, legal professionals, as well as UNHCR officials. One of these guidelines is guideline no. 9: Guidelines on International Protection No. 9 Claims to Refugee Status based on Sexual Orientation and/or Gender Identity within the context of Article 1A(2) of the 1951 Convention and/or its 1967 Protocol relating to the Status of Refugees. The guideline states that

refugee claims based on sexual orientation and/or gender identity are most commonly recognized under the "membership of a particular social group" ground. Other grounds may though also be relevant depending on the political, religious and cultural context of the claim. For example, LGBTI activists and human rights defenders (or perceived activists/defenders) may have either or both claims based on political opinion or religion if, for example, their advocacy is seen as going against prevailing political or religious views and/or practices.

Furthermore, the Yogyakarta Principles constitute an important foundation to orient the application of Human Rights revolving around questions linked to sexual orientation and gender identity. In principle 23, it is stated "Everyone has the right to seek and enjoy in other countries asylum from persecution, including persecution related to sexual orientation or gender identity".

Again according to Yogyakarta, sexual orientation is defined as "each person's capacity for profound emotional, affectional and sexual attraction to, and intimate relations with, individuals of a different gender or the same gender or more than one gender". Gender identity refers to "each person's deeply felt internal and individual experience of gender, which may or may not correspond with the sex assigned at birth, including the personal sense of the body and other expressions of gender, including dress, speech and mannerisms".

\section{CONCLUSION}

One can conclude that the LGBTI refugee is an individual who cannot perceive other alternatives than that of fleeing his or her country to build a better life. Is it to be hoped that one day, LGBTI individuals may not be forced to leave their countries due to persecution.

Year by year countries launch laws that help to improve LGBTs rights, but still many countries criminalize homossexuality. Asylum law around the world should expand "particular social group" to include LGBT individuals persecuted in their home countries. This will help people around the world to 
connect and create networks which can help these people, and also avoid experiences such as death and sentences of prision for people just due to the fact of being LGBT.

\section{REFERENCES}

UNHCR. The UN Refugee Agency. Available on: http://www.acnur.org/t3/portugues/noticias/noticia/perseguidos-por-sua-orientacao-sexualrefugiados-lgbti-conseguem-protecao-no-brasil/ Access on: 10-03-2015.

UNHCR. The 1951 Refugee Convention. Available on: < http://www.acnur.org/t3/fileadmin/Documentos/portugues/BDL/Convencao relativa ao Estatuto dos Refugiados.pdf?view=1> Access on: 25/06/2015.

BAUMAN, Zygmunt. Identidade: entrevista a Benedetto Vecchi; tradução, Carlos Alberto Medeiros. Rio de Janeiro: Jorge Zahar Ed., 2005.

Guidelines number 09 of UNHCR. Available on: http://www.acnur.org/t3/fileadmin/Documentos/BDL/2014/9748.pdf?view=1

Access on: 20/06/2015

FOUCAULT, M. História da sexualidade 1. Ed. Graal - RJ, 1985. . História da sexualidade 2: o uso dos prazeres. Jorge Zahar - RJ, 1994.

Handbook and Guidelines on Procedures and Criteria for determining Refugee Status, 2011. Disponível em: http://www.unhcr.org/3d58e13b4.html Acesso em: 23-05-2015.

HENES, Brian F. The Origin and Consequences of Recognizing Homosexuals as a "particular social group" for refugee purposes. Brian F. Henes Available on:<http://heinonline.org/HOL/LandingPage?handle=hein.journals/tcli8\&div=18\&id=\&page=> Access on: $22 / 06 / 2015$.

JANSEN, Sabine; SPIJKERBOER, Thomas. Fleeing Homophobia - Asylum Claims Related to Sexual Orientation and Gender Identity in Europe. COC Nederland, 2011.

JUBILUT, Liliana Lyra. O Direito Internacional dos Refugiados e sua aplicação no ordenamento jurídico brasileiro. São Paulo: Método, 2007, p. 132.

LGBT Asylum. Available on: http://www.lgbtasylum.dk/ Access on: 21-05-2015

LGBT Asylum Support Task Force. Available on: http://www.lgbtasylum.org/ Access on: 21-05-2015.

MAROUF, Fatma E. The Emerging Importance of "Social Visibility" in Defining a "Particular Social Group" and Its Potential Impact on Asylum Claims Related to Sexual Orientation and Gender Yale Law \& Policy Review, Vol. 27, No. 1 (Fall, 2008) Available on: < http://www.jstor.org/stable/40239706> Access on: 29/06/2015

PARISH, T. David. Membership in a Particular Social Group under the Refugee Act of 1980: Social Identity and the Legal Concept of the Refugee. Columbia Law Review Association, Volume 
92, number 4 (May 1992), p. 923 Available on: http://www.jstor.org/stable/1122973?seq=1\#page scan tab contents Access on: 23-05-2015.

PERRYMAN, Benjamin; MORRISH, Deborah; KASSAM, Abbas. The Nebulous Nexus Between Sexual Orientation and Membership in a Particular Social Group. Available on: http://www.iarli.org/general/images/stories/Tunis conference/WPPapers/Human Rights Working Part y.pdf Access on: 25/06/2015

Yogyakarta Principles, art. 23 Available on: http://www.yogyakartaprinciples.org/ Access on : 07/06/2015

SHARLET, Jeff. Protecting the Human Rights of LGBT Rights of LGBT People in Uganda in the Wake of Uganda's “Anti Homossexuality Bill, 2009. ADVOCATE, Sep. 2010, at 36.

\section{COMO CITAR ESSE DOCUMENTO:}

NASCIMENTO, Daniel Braga; HAAS, Emilie de; BAGGIO, Roberta Camineiro. Migration due to sexual orientation and gender identity. Revista do Direito, Santa Cruz do Sul, v. 1, n. 51, jul. 2017. ISSN 1982-9957. Disponível em: <https://online.unisc.br/seer/index.php/direito/article/view/9442>. Acesso em: . doi:http://dx.doi.org/10.17058/rdunisc.v1i51.9442. 